\title{
EXTENT OF DIFFUSION OF ORGANIC MOLECULES IN THE ENAMEL TISSUE OF DOGS
}

\author{
TIHAČEK - ŠOJIĆ LJILJANA \\ Faculty of stomatology, Belgrade \\ (Received 15 July, 2004)
}

The objective of this study was to evalute the extent of diffusion of organic molecules in the enamel tissue, of permanent teeth. The experimental study was performed in vivo on dogs.

To the experomental dogs the molars on the right side of the lower jaw underwent enamel tissue reduction without additionaly placing any tooth protection. Teeth on the left side of the lower jaw were left intact thus rapresenting the control.

After 12 months animals were sacrificed,experimental and control teeth extracted and the study of diffusion in vitro carried on. For that purpose an organic spin marker 4-amino - 2,2,6,6,-tetramethylpiperdinyl 1-oxi (4-Amino-Tempo) was selected. The property of this marker is that it contains a nitroxide radical which is stable in a neutral and base enviroment, and due to the unbound spin of the free radical it is higly siutable for the electronic paramagnetic resonance method (EPR).

Studies on the diffusion of organic spin markers in the enamel tissue are performed by submerging the prepared tooth in a water solution containing the marker substance. From the intensity of the EPR spectrum filmed after tooth withdrawal from the water solution, distribution, diffusion time and penetration depth of marker molecules were established. Coefficients of organic spin marker diffusion and saturation concentrations of marker molecules in the enamel were determined. The observed variations in the areal and time for disribution of diffused molecules were explained by the binding possibility of the $N$ $O$-radical from the marker molecule to the enamel tissue. The results of the experiment contained in this work contribute to a better understanding of the spin marker organic molecule movement through the enamel tissue which is controlled by the mechanism of diffusion and chemical bonding of the marker molecule to the enamel structure.

The results of the experimental research also indicate the harmful effects of leaving the enamel tissue without protection.

Key words: diffusion, enamel tissue, diffusion coefficient, EPR. 


\section{INTRODUCTION}

The enamel tissue is continuously exposed to the effect of agents which can be augmented by the effects of preparations and materials applied locally on the tissue.

We meet every day with a great number of new materials introduced in the dentistry practice. The mechanism of their effect on the enamel tissue is in the greatest number of cases, invastigated only within clinical studies. The basis for testing the effect of a new dentistry material on the dental tissue is the chemical composition of the material and the histological structure of the dental tissues, whereas there are still not valid data on the dynamics of diffusion processes.

Reduction of the enamel tissue in the daily dental practice is performed for the purpose of:

- occlusion adaptation by selective driling and

- preparation of teeth for receiving the elements of a partial skeletal prothesis,

Reduced enamel is exposed to the effect of the external harmful agents which result in irreversible changes. In order to make possible the protection of enamel it is necessary to know the dynamics of diffusion processes of organic structures through the enamel tissue.

The mechanisms of the effect of all these diverse chemical structures depend primarily on:

- chemical composition of the material,

- properties of the bilateral diffusion process through the enamel tissue,

- manner of binding to the enamel tissue and

- enamel tissue structure.

Diffusion is a process of mutual amalgamation of gases, liquids and solids. Good knowledge of the dynamics of diffusion processes through the oral tissues contributes to:

I. clarification of the mechanism of penetration of harmful agents from the environment,

II. research of biological effects of dental material under in vivo and in vitro conditions,

III. protection of functional and anatomic integrity of oral tissues.

Vrbošek and Ravnik et al. (1973), Zipkin (1964) and Weatherell et al. $(1965 ; 1977)$ state that the process of diffusion through crystal structures takes place as several different mechanisms of movement of atoms and atomic groups within a crystal grid.

The structures of the crystal grid are not always ideal and contain certain imperfections which may be expressed as:

I. dot defects stemming from evacuated atomic places in the crystal grid (Gwinett, 1966;1967),

II. line defects or defects within the plane, which represent a dislocation or layered atom vacencies (Little et al; 1966) and

III. complex of defects which are a result of interaction or fusing of primary defects.(Ripa, 1966). 
The direction of the diffusion process through the enamel tissues has two diverse direction, Tihaček Šojić (1996):

I. CENTRIPETAL DIFFUSION which takes place from the surface of the enamel tissues towards its interior and

II. CENTRIFUGAL DIFFUSION whose direction is from the enamel-dentine border to the surface of the enamel tissue.

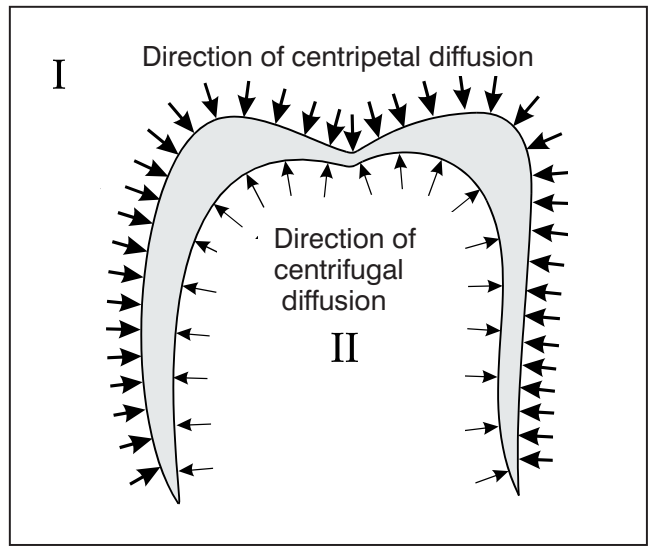

Figure 1. Directions of diffusion processes through the enamel tissue:

a) centripetal direction,

b) centrifugal direction

Beloica et al. (1980), Borowsky (1978), Cevs et al. (1986), Skalerić et al. $(1974 ; 1986)$ and Tihaček Sojić $(1992 ; 1993)$. The surface of the enamel tissue is exposed to the effect of a great quantity of diverse organic and inorganic substances originating from the saliva, food, dental plaque and dental material due to which the diffusion from the centripetal direction, namely from the surface of the enamel tissue towards the interior, is very intesive. At the same time the centrifugal direction of diffusion cannot be neglected in spite of the smaller quantity of particles whose diffusion is possible, in view of:

I. density of the enamel tissue

II. size of the interprysm space and

III. dentine structure

The density value of the enamel tissue is greatest on the enamel surface and has a tendency of dropping towards the enamel-dentine border Silverstone (1986), Stearns (1971), Stern et al. (1985) and Toth et al. (1986).

The size of the interprysm space, contary to the enamel, grows from the enamel surface towards the enamel-dentine border. Young (1974) and Schwancar (1970) state that dentine at the level of the enamel-dentine border has openings of dentine tubules whose mean diameter is $1.74 \mathrm{fim}$ so that an undisturbed centrifugal direction of diffusion is possible. 
The diffusion of particles is carried out through the enamel mostly in one direction, but in both senses and is called the Bilateral diffusion. It represents a physiological diffusion.

The research performed up to now on the diffusion processes (Borggreven et al. 1980, Funduk et al.,1986 and Kambara,1977) through the dental tissues relates only to the unilateral diffusion of inorganic molecules, namely to the determination of the intesity of the centripetal direction of diffusion, which moves from the enamel tissue surface to the enamel-dentine border. Other tissue surfaces were considered hermetically closed, Johnson (1971), Borowsky (1978), Burke (1975), Doi (1986) and Spektrova (1967).

On analysis of unilateral water diffusion processes through the enamel tissue (Dibdin, 1972 and Chick, 1963) a diffusion coefficient was obtained:

$$
\mathrm{DH}_{2} \mathrm{O}=(1.16+0.08) \times 10^{-8} \mathrm{~cm}^{2} / \mathrm{s}, \quad \mathrm{t}=20^{\circ} \mathrm{C}(1)
$$

Coefficients of the unilateral diffusion through the enamel tissue for sodium and manganese ions, according to Arwill (1965), Kambara (1977), and Funduk (1975), amount to:

$$
\begin{array}{ll}
\mathrm{D}_{\mathrm{Na}}{ }^{+}=2.0 \times 10^{-10} \mathrm{~cm}^{2} / \mathrm{s}, & \mathrm{t}=20^{\circ} \mathrm{C} \mathrm{(2)} \\
\mathrm{D}_{\mathrm{Mn} 2}{ }^{+}=1.4 \times 10^{-} \mathrm{cm}^{2} / \mathrm{s}, & \mathrm{t}=20^{\circ} \mathrm{C} \mathrm{(3)}
\end{array}
$$

Data on the diffusion of organic molecules through the enamel tissue has been found in only a few published articles Waters (1971) and Tihaček Šojić (1996).

The aim of the research was to determine properties of transport and distribution of organic molecules in the enamel tissue.

\section{MATERIAL AND METHODS}

For the research of the properties of the bilateral organic molecule diffusion in the enamel a water solution of an organic 4-Amino-Tempo spin marker was used. The concentration of the marker was $\mathrm{C}=0.02335 \mathrm{M}\left(250 \mathrm{ml} \mathrm{H}_{2} \mathrm{O}+1 \mathrm{gr}\right.$ Marker) and the number of spins $M s=7 \times 10^{16} / 0.0005 \mathrm{~cm}^{3}$. According to its structure the marker is similar to the toxins (or parts of toxins) of oral bacteria, as well as the detritus that can be found in the saliva and dental plaque. Its empirical formula is $\mathrm{C}_{9} \mathrm{H}_{19} \mathrm{~N}_{2} \mathrm{O}$, molecular weight 171.3 , and the structural formula is presented on Figure 2.

The oxygen within the nitrogen oxide radical has an unpaired electron $-0^{\circ}$, and the electronic configuration $1 s^{2} 2 s^{2} \mathrm{ps}^{2}$ has a spin $S=1 / 2$ and orbital moment $\mathrm{L}=1$.

Molecules that have an unpaired electron with $\mathrm{S}$ spin are paramagnetic molecules which make paramagnetic centers in the diamagnetic matrix.

Organic spins marker 4-Amino-Tempo with a stable nitrogen oxide radical rapresents a paramagnetic molcule whose EPR spectrum has a characteristic 
triplet structure, which is presented at Figure 3. The value of the first integral of the first derivative of the EPR spectrum is presented in Figure 4.

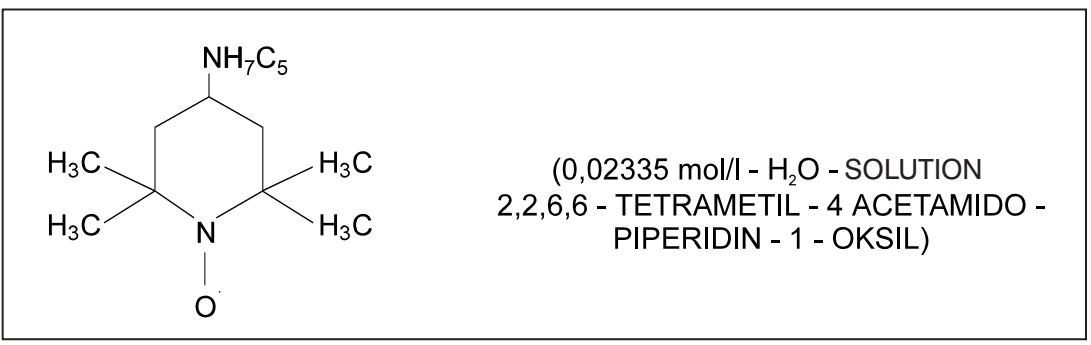

Figure 2. Structural formula of oganic 4-Amino-Tempo spin marker

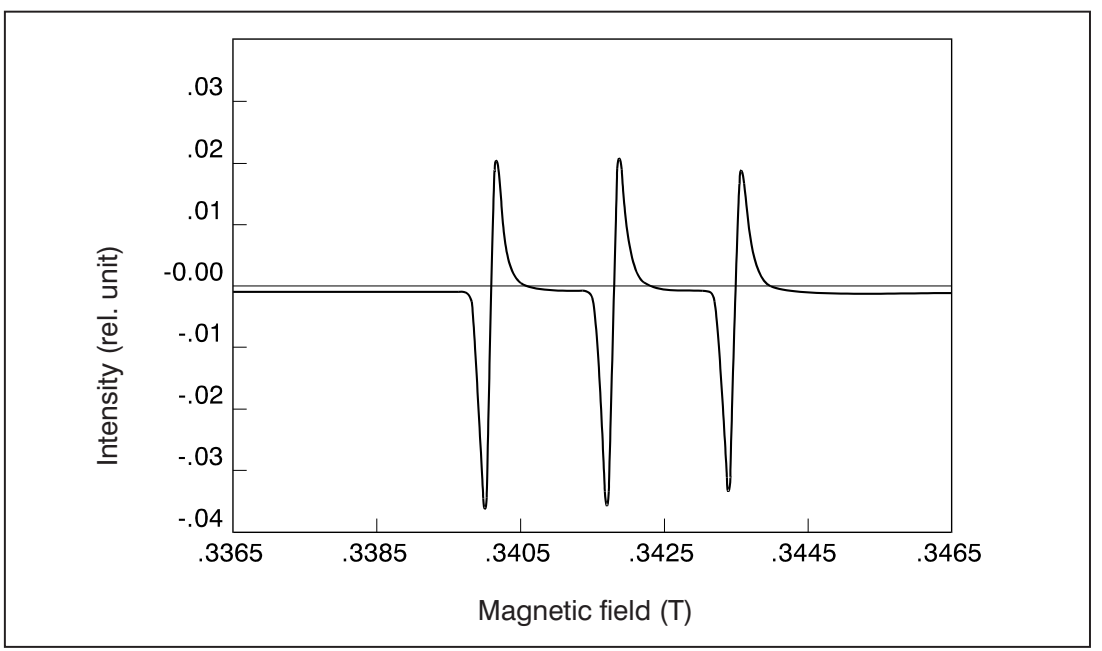

Figure 3. First derivation of the ERP spectrum obtained on the water solution of the 4-Amino-Tempo marker concentration $\mathrm{C}=0.02335 \mathrm{M}$

Three groups of enamel tissue preparations, prepared in different ways, have been used as a test material.

The experimental stady in vivo was performed on three dogs.

Molars on right side of the lower jaw, in all experimental animals had enamel tissue reduction, without putting protection, while teeth on left side were intact and they represent the control group. After 12 months animals were sacrified, experimental and control teeth extracted and the studing of diffusion carried on in vitro. 


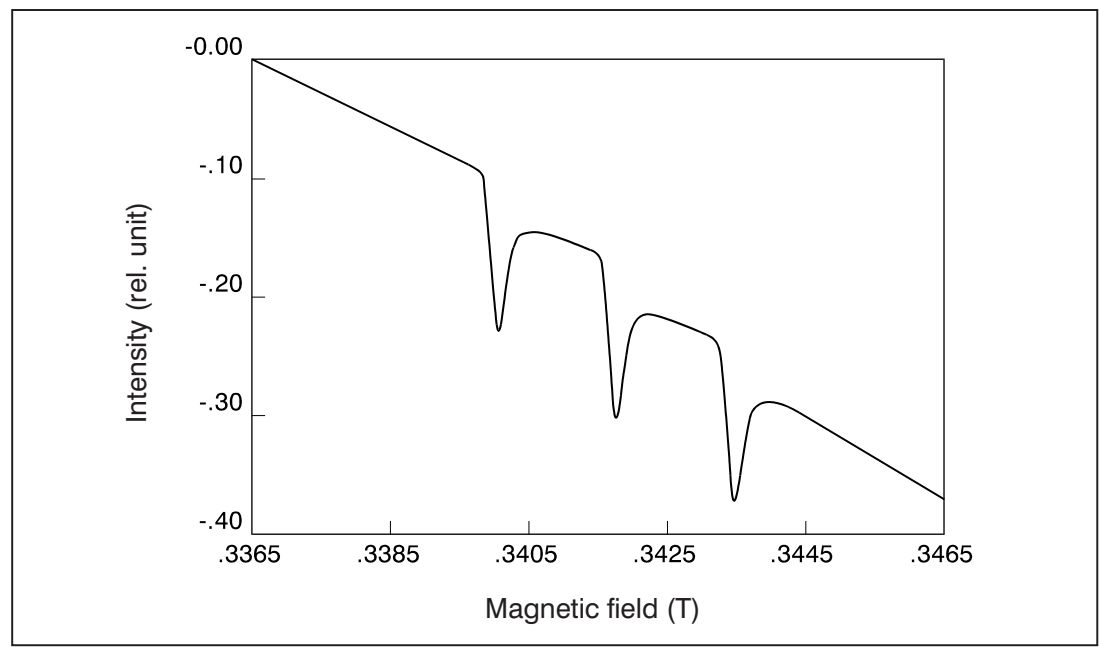

Figure 4. Integral of the first derivation of EPR spectrum of water solution of 4 Amino-Tempo marker concentration $\mathrm{C}=0,02335 \mathrm{M}$

The size of the prepared enamel prepatations was approximately $0.4 \mathrm{~cm} \times$ $0.3 \mathrm{~cm} \times 0.25 \mathrm{~cm}$, where the $\mathrm{h}=0.4 \mathrm{~cm}$ is the cervico-occlusion orientation, $\mathrm{s}$ $=0.3 \mathrm{~cm}$ vestibulo-oral orientation and $\mathrm{I}=0.25 \mathrm{~cm}$ thickness of the enamel.

Based on the mode of sample and tissue preparation the experimental groups were formed in the following way:

I GROUP - Intact enamel - samples of the intact enamel tissue obtained from extracted intact teeth of experimental dogs.

II GROUP - Young non-intact enamel - enamel tissue was reduced after tooth extraction.

III GROUP - Old non-intact enamel - Reduction of enamel tissue was performed one year prior to the extraction of the tooth. Protection of the reduced enamel tissue has not been performed.

Immediately after tooth extraction in a dog, enamel tissue preparation was cut out by a high velocity machine with a diamond grinding plate. Checking for the presence of dentine was made with a UV light. For each group 20 preparations of enamel tissue were made.

Observation on EPR Spectrometer was performed prior to the immersion in the organic spin marker solution. None of the samples showed the presence of resonant signals which would be a consequence of paramagnetic centers within. The prepared preparations could thus be used in further experiments with marker diffusion.

All samples were marked and immersed in the water solution of organic spin marker 4-Amino-Tempo. The time of monitoring the bilateral diffusion process was for the 1st and 2nd group 842.5 hours (35 days), and for the 3rd group 1010.5 hours (42 days). 
The method of electronic paramagnetic (spin) resonance, representing a spectroscopy method, was used for the test. The experiment was carried out by an EPR Spectrometer Varian E-9 at the Institute for Nuclear Sciences in Vinča.

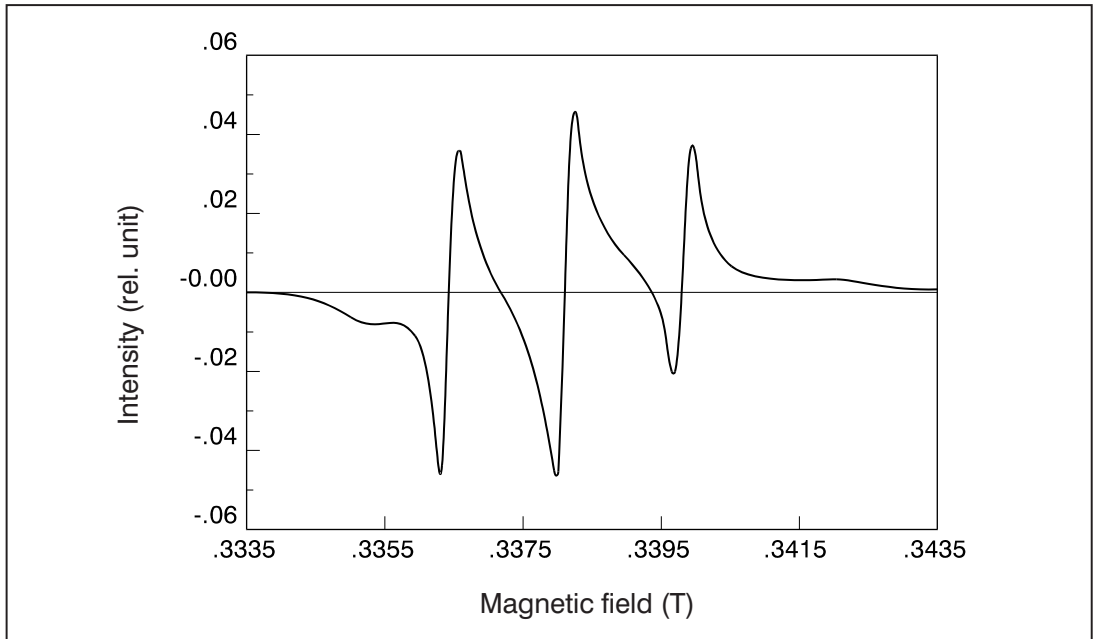

Figure 5. First derivative of EPR spectrum opserved on the preparation of intact enamel tissue $\left(6_{5}\right)$ held in a water solution of 4-Amino-Tempo marker for 46 hours at a temperature of $t=17^{\circ} \mathrm{C}$

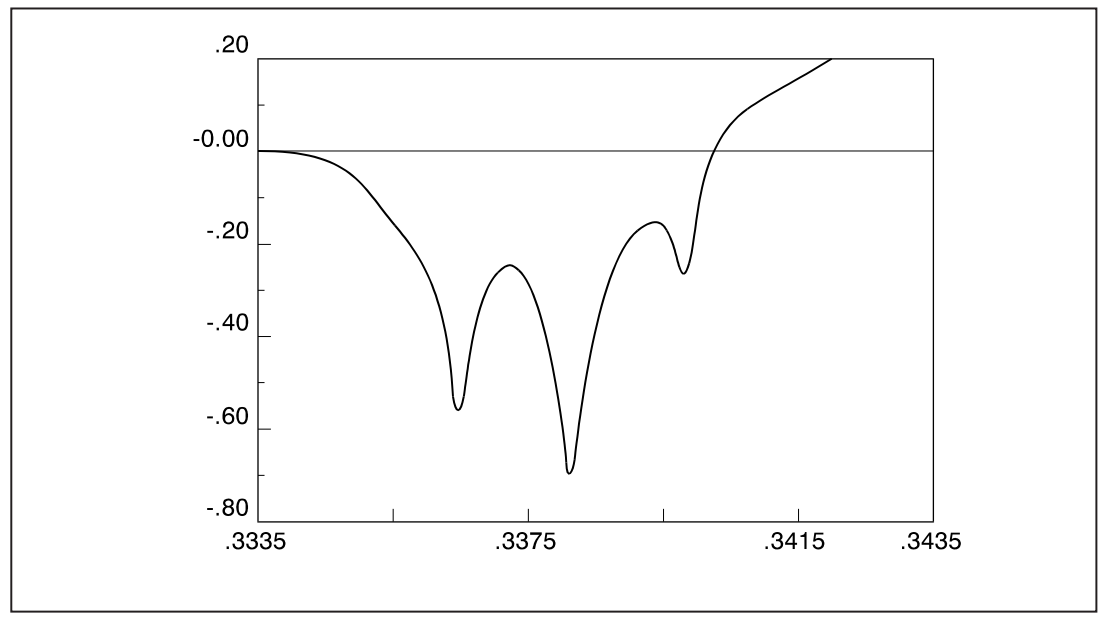

Figure 6. Integral of the first derivative of ERP spectrum of preparation of intact enamel tissue $\left(6_{5}\right)$ observed after 46 hours of diffusion of 4-AminoTempo at a temperature of $\mathrm{t}=17^{\circ} \mathrm{C}$ 
The quantity of diffused paramagnetic marker molecules was determined by measurements of the EPR enamel spectrum at different time intervals. The enamel samples (rinsed with distilled water and dried) were placed within a test tube in the EPR Spectrograph resonant cuvette. Within the range of the magnetic field of the resonant cuvette there was an interaction of the magnetic effects and paramagnetic molecules was detected by the appearance of a triplet spectrum.

The spectrums are detected by the EPR Spectrometer (Figure 5) and the integrals of the first derivative of the EPR spectrum have been calculated by a special computer program (Figure 6).

\section{RESULTS}

Analysis of the bilateral process of organic spin 4-Amin-Tempo marker diffusion in dogs, enamel tissue was made by measurements of the first derivative of the EPR spectrum, of all three groups in defined time intervals. Determination of the values of the integrals below the central absorption line was observed for all spectrums.

\section{GROUP - INTACT ENAMEL}

Table 1. Samples of the 1st Group - Intact enamel: Values of integrals, number of molecules in the entire volume of the sample and number of molecules that have entered a sample per unit of surface

\begin{tabular}{|c|c|c|c|c|c|}
\hline Sec & Hours & Days & Integrals & $Q_{\text {mer }}$ & $\begin{array}{c}Q=Q_{\text {mer }} / \text { sh } \\
\left(1 / \mathrm{cm}^{2}\right)\end{array}$ \\
\hline \hline $1.818 \times 10^{5}$ & 50.5 & 2 & - & - & - \\
\hline $3.546 \times 10^{5}$ & 98.5 & 4 & - & - & - \\
\hline $6.138 \times 10^{5}$ & 170.5 & 7 & 2.43 & $4.2 \times 10^{14}$ & $42 \times 10^{14}$ \\
\hline $8.730 \times 10^{5}$ & 242.5 & 10 & 3.74 & $5.6 \times 10^{14}$ & $56 \times 10^{14}$ \\
\hline $2.186 \times 10^{5}$ & 338.5 & 14 & 3.66 & $5.6 \times 10^{14}$ & $56 \times 10^{14}$ \\
\hline $13.914 \times 10^{5}$ & 386.5 & 16 & 4.05 & $6.1 \times 10^{14}$ & $61 \times 10^{14}$ \\
\hline $15.642 \times 10^{5}$ & 434.5 & 18 & 4.59 & $6.8 \times 10^{14}$ & $68 \times 10^{14}$ \\
\hline $18.234 \times 10^{5}$ & 506.5 & 21 & 4.17 & $6.2 \times 10^{14}$ & $62 \times 10^{14}$ \\
\hline $19.962 \times 10^{5}$ & 554.5 & 23 & 3.82 & $5.8 \times 10^{14}$ & $58 \times 10^{14}$ \\
\hline $21.690 \times 10^{5}$ & 602.5 & 25 & 4.53 & $6.6 \times 10^{14}$ & $66 \times 10^{14}$ \\
\hline $24.282 \times 10^{5}$ & 674.5 & 28 & 4.13 & $6.2 \times 10^{14}$ & $62 \times 10^{14}$ \\
\hline $26.010 \times 10^{5}$ & 722.5 & 30 & 4.95 & $7.2 \times 10^{14}$ & $72 \times 10^{14}$ \\
\hline $27.738 \times 10^{5}$ & 770.5 & 32 & 4.67 & $6.8 \times 10^{14}$ & $68 \times 10^{14}$ \\
\hline $30.330 \times 10^{5}$ & 842.5 & 35 & 4.87 & $7.2 \times 10^{14}$ & $72 \times 10^{14}$ \\
\hline $33.786 \times 10^{5}$ & 890.5 & 37 & - & - & - \\
\hline $37.242 \times 10^{5}$ & 938.5 & 39 & - & - & - \\
\hline $38.970 \times 10^{5}$ & 1010.5 & 42 & - & - & - \\
\hline
\end{tabular}


The Table 1 presents the values of integral I, the number of unbound molecules of markers that have diffused through the intact enamel over the entire volume of the sample $Q_{\text {mer }}$, and the number of unbound molecules that have entered the sample with thickness I per surface

$$
\mathrm{Q}=\mathrm{Qmer} / \mathrm{sh} \quad \text { for different diffusion times. }
$$

The number of diffused molecules of $Q$ marker in a sample of intact enamel is presented in Figure 7.

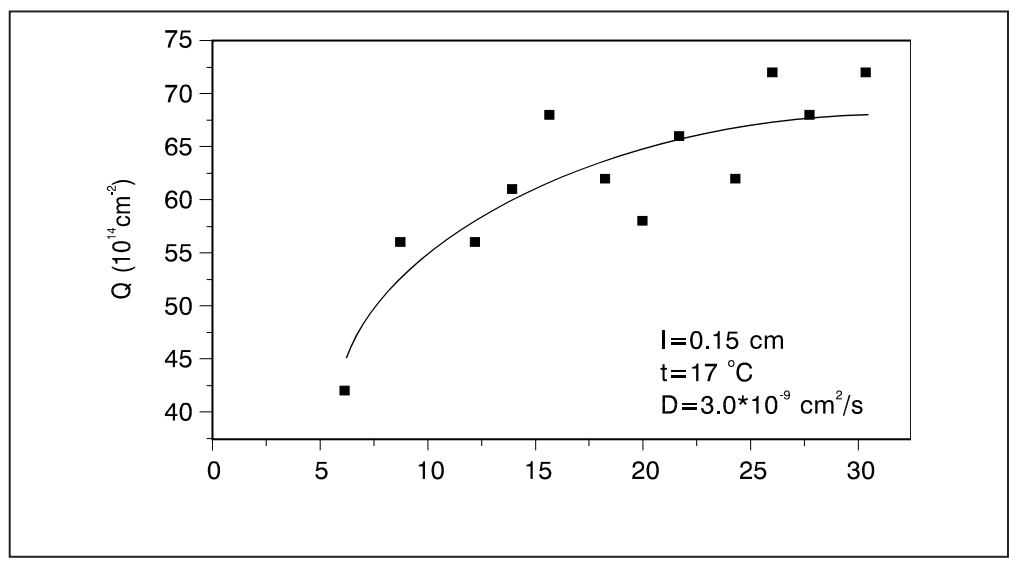

Figure 7. Number or unbound marker molecules that have entered the intact enamel, thickness $I=0.15 \mathrm{~cm}$, per unit of sample surface subject to diffusion time

\section{I/ GROUP - YOUNG NON-INTACT ENAMEL}

Parameters of molecule marker diffusion in the young non-intact enamel tissue determined from the EPR spectrum of these samples are presented in Table 2 .

The dependence on the of the diffusion of $Q$ marker molecules in the young non-intact enamel is presented in Figure 8. 
Table 2. Samples of the 2nd Group - Young non-intact enamel: Values of integrals, number of molecules in the entire volume of the sample and number of molecules that have entered a sample per unit of surface

\begin{tabular}{|c|c|c|c|c|c|}
\hline Sec & Hours & Days & Integrals & $Q_{\text {mer }}$ & $\begin{array}{c}Q=Q_{\text {mer }} / \mathrm{sh} \\
\left(1 / \mathrm{cm}^{2}\right)\end{array}$ \\
\hline \hline $1.818 \times 10^{5}$ & 50.5 & 2 & 0.56 & $2.2 \times 10^{14}$ & $24.4 \times 10^{14}$ \\
\hline $3.546 \times 10^{5}$ & 98.5 & 4 & 1.08 & $2.8 \times 10^{14}$ & $31.1 \times 10^{14}$ \\
\hline $6.138 \times 10^{5}$ & 170.5 & 7 & 1.18 & $2.9 \times 10^{14}$ & $32.2 \times 10^{14}$ \\
\hline $8.730 \times 10^{5}$ & 242.5 & 10 & 1.39 & $3.1 \times 10^{14}$ & $34.4 \times 10^{14}$ \\
\hline $12.186 \times 10^{5}$ & 338.5 & 14 & - & - & - \\
\hline $13.914 \times 10^{5}$ & 386.5 & 16 & 2.81 & $4.6 \times 10^{14}$ & $51.1 \times 10^{14}$ \\
\hline $15.642 \times 10^{5}$ & 434.5 & 18 & 3.20 & $5.1 \times 10^{14}$ & $56.7 \times 10^{14}$ \\
\hline $18.234 \times 10^{5}$ & 506.5 & 21 & 2.80 & $4.6 \times 10^{14}$ & $51.1 \times 10^{14}$ \\
\hline $19.962 \times 10^{5}$ & 554.5 & 23 & 3.22 & $5.1 \times 10^{14}$ & $56.7 \times 10^{14}$ \\
\hline $21.690 \times 10^{5}$ & 602.5 & 25 & 3.17 & $5.0 \times 10^{14}$ & $55.6 \times 10^{14}$ \\
\hline $24.282 \times 10^{5}$ & 674.5 & 28 & 3.61 & $5.6 \times 10^{14}$ & $62.2 \times 10^{14}$ \\
\hline $26.010 \times 10^{5}$ & 722.5 & 30 & 3.45 & $5.4 \times 10^{14}$ & $60.0 \times 10^{14}$ \\
\hline $27.738 \times 10^{5}$ & 770.5 & 32 & - & - & - \\
\hline $30.330 \times 10^{5}$ & 842.5 & 35 & 3.19 & $5.1 \times 10^{14}$ & $56.7 \times 10^{14}$ \\
\hline $33.786 \times 10^{5}$ & 890.5 & 37 & - & - & - \\
\hline $37.242 \times 10^{5}$ & 938.5 & 39 & - & - & - \\
\hline $38.970 \times 10^{5}$ & 1010.5 & 42 & - & - & - \\
\hline
\end{tabular}

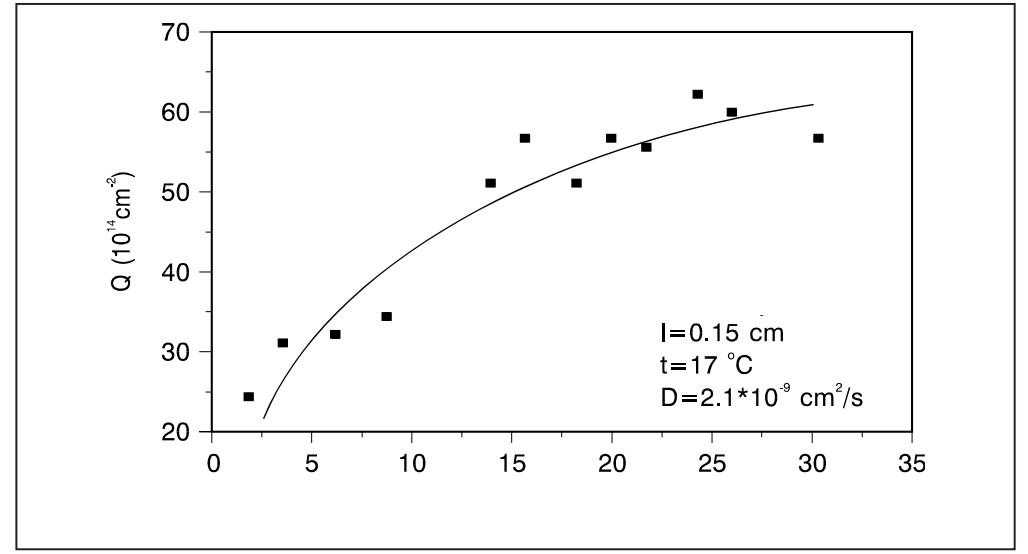

Figure 8. Number or unbound marker molecules that have entered the young non-intact enamel, thickness $I=0.15 \mathrm{~cm}$, per unit of sample surface subject to diffusion time 
Acta Veterinaria (Beograd), Vol. 55. No. 1, 53-68, 2005.

Tihaček-Šojić Ljiljana: Extent of diffusion of organic molecules

in the enamel tissue of dogs

\section{GROUP - OLD NON-INTACT ENAMEL}

Table 3. Samples of the 3rd Group - Old non-intact enamel: Values of integrals, number of molecules in the entire volume of the sample and number of molecules that have entered a sample per unit of surface

\begin{tabular}{|c|c|c|c|c|c|}
\hline Sec & Hours & Days & Integrals & $Q_{\text {mer }}$ & $\begin{array}{c}Q=Q_{\text {mer }} / \mathrm{sh} \\
\left(1 / \mathrm{cm}^{2}\right)\end{array}$ \\
\hline \hline $1.818 \times 10^{5}$ & 50.5 & 2 & 1.07 & $5 \times 10^{14}$ & $45.5 \times 10^{14}$ \\
\hline $3.546 \times 10^{5}$ & 98.5 & 4 & 1.66 & $5.6 \times 10^{14}$ & $50.9 \times 10^{14}$ \\
\hline $6.138 \times 10^{5}$ & 170.5 & 7 & 2.01 & $6.3 \times 10^{14}$ & $57.3 \times 10^{14}$ \\
\hline $8.730 \times 10^{5}$ & 242.5 & 10 & - & - & - \\
\hline $12.186 \times 10^{5}$ & 338.5 & 14 & 2.43 & $6.6 \times 10^{14}$ & $60.0 \times 10^{14}$ \\
\hline $13.914 \times 10^{5}$ & 386.5 & 16 & 2.37 & $6.5 \times 10^{14}$ & $59.1 \times 10^{14}$ \\
\hline $15.642 \times 10^{5}$ & 434.5 & 18 & 3.17 & $7.5 \times 10^{14}$ & $68.2 \times 10^{14}$ \\
\hline $18.234 \times 10^{5}$ & 506.5 & 21 & 2.95 & $7.0 \times 10^{14}$ & $63.6 \times 10^{14}$ \\
\hline $19.962 \times 10^{5}$ & 554.5 & 23 & 2.91 & $7.0 \times 10^{14}$ & $63.6 \times 10^{14}$ \\
\hline $21.690 \times 10^{5}$ & 602.5 & 25 & 2.64 & $6.7 \times 10^{14}$ & $60.9 \times 10^{14}$ \\
\hline $24.282 \times 10^{5}$ & 674.5 & 28 & 2.84 & $6.9 \times 10^{14}$ & $62.7 \times 10^{14}$ \\
\hline $26.010 \times 10^{5}$ & 722.5 & 30 & 2.74 & $6.8 \times 10^{14}$ & $61.8 \times 10^{14}$ \\
\hline $27.738 \times 10^{5}$ & 770.5 & 32 & 2.84 & $6.9 \times 10^{14}$ & $62.7 \times 10^{14}$ \\
\hline $30.330 \times 10^{5}$ & 842.5 & 35 & 2.76 & $6.8 \times 10^{14}$ & $61.8 \times 10^{14}$ \\
\hline $33.786 \times 10^{5}$ & 890.5 & 37 & 2.93 & $7.0 \times 10^{14}$ & $63.6 \times 10^{14}$ \\
\hline $37.242 \times 10^{5}$ & 938.5 & 39 & - & - & - \\
\hline $38.970 \times 10^{5}$ & 1010.5 & 42 & - & - & - \\
\hline
\end{tabular}

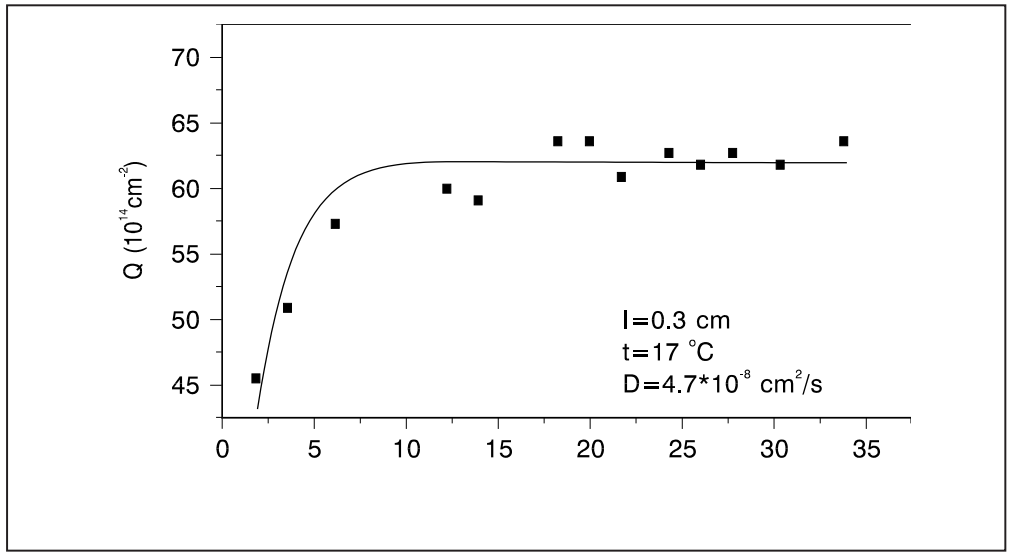

Figure 9. Number or unbound marker molecules that have entered the old non-intact enamel, thickness $I=0.3 \mathrm{~cm}$, per unit of sample surface subject to diffusion time 
Interprysmatic spaces of experimental teeth were accessible to imbibition of defferent agents from the environment, before the beginning of the experiment while still in the dog's mouth. The market diffusion parameters in the old non-intact enamel are presented in Table 3, and the dependence of the number of diffused molecules on time of diffusion is presented on Figure 9.

The experimentally determined dependence of the number of diffused marker molecules in the enamel tissue for a sufficient diffusion time may be approximated by the formula:

$$
\mathrm{Q}=\mathrm{N}_{\mathrm{o}} 1\left(1-8 / \pi^{2} \varphi-\pi^{2} \mathrm{Dt} / /^{2}\right)
$$

where $I$ = sample thickness, $N_{0}$ - number of particles and D - diffusion coeficient. Full lines on figures 7, 8 and 9 represent the dependence (4) adjusted to the experimental value.

The saturation value of the number of diffused molecules and the diffusion parameters at a temperature $t=17^{\circ} \mathrm{C}$ are presented on Table 4 .

Table 4. Saturation value of the number of diffused marker molecules and diffusion coefficient at a temperature of $\mathrm{t}=17^{\circ} \mathrm{C}$

\begin{tabular}{|c|c|c|c|c|c|}
\hline Preparations & $\mathrm{I}(\mathrm{cm})$ & $\mathrm{s}(\mathrm{cm})$ & $\mathrm{h}(\mathrm{cm})$ & $\mathrm{N}_{0} \mathrm{l}\left(\mathrm{cm}^{-2}\right)$ & $\mathrm{D}\left(\mathrm{cm}^{2} \mathrm{~s}^{-1}\right)$ \\
\hline \hline$(1)$ & 0.15 & 0.20 & 0.50 & $69.3 \times 10^{14}$ & $3.0 \times 10^{-9}$ \\
\hline$(2)$ & 0.15 & 0.20 & 0.45 & $65.0 \times 10^{14}$ & $2.1 \times 10^{-9}$ \\
\hline$(3)$ & 0.30 & 0.20 & 0.55 & $61.7 \times 10^{14}$ & $4.7 \times 10^{-8}$ \\
\hline
\end{tabular}

\section{DISCUSSION}

Organic molecules of the 4-Amino-Tempo spin marker organic molecules diffused through the enamel tissue thanks to its molecular structure and high reactivity of the nitrogen oxide radical.

The bilateral process of marker diffusion going on in the enamel tissue is characterized by concentration of diffused molecules and diffusion coefficient.

It was observed that the inact enamel and the freshly reduced enamel tissue show similar behavior with respect to diffusion. Saturation of diffused marker molecule occurs after 4-5 weeks, which is also corroborated by the same saturation concentration of the diffused marker molecules:

$$
\begin{array}{ll}
\mathrm{No}^{I G}=0.46 \times 10^{17} \mathrm{~cm}^{-3} & \text { INTACT ENAMEL } \\
\mathrm{No}^{\mathrm{RG}}=0.43 \times 10^{17} \mathrm{~cm}^{-3} & \text { YOUNG NON-INTACT ENAMEL }
\end{array}
$$

And approximately the same diffusion coefficient:

$$
\begin{aligned}
& D^{I G}=3.0 \times 10^{9} \mathrm{~cm}^{2} \mathrm{~S}^{-1} \\
& \mathrm{D}^{\mathrm{rG}}=2.1 \times 10^{9} \mathrm{~cm}^{2} \mathrm{~S}^{-1} \\
& \mathrm{t}=17^{\circ} \mathrm{C}
\end{aligned}
$$


Contrary to these tissues the reduced enamel tissues which had been in the dog's mouth for a long time (period of one year) without protection, had a smaller saturation value of concentration of diffused marker molecules.

$$
\mathrm{No}^{\mathrm{SIG}}=0.21 \times 10^{17} \mathrm{~cm}^{-3} \quad \text { (OLD NON-INTACT ENAMEL) }
$$

Marker molecules appear after 10 days showing a significantly higher diffusion coefficient:

$$
\mathrm{D}^{\mathrm{SRG}}=4.7 \times 10^{8} \mathrm{~cm}^{2} \mathrm{~s}^{-1}, \quad \mathrm{t}=17^{\circ} \mathrm{C}
$$

Faster diffusion and penetration of organic molecules into the old non-intact enamel tissue indicates the harmful effects of leaving reduced enamel without protection.

In monitoring the diffusion process oscillations of the number of diffused marker molecules around the monotonous dependence of their concentration on the time and thickness of the preparation, which indicates the process of binding the marker molecules in the enamel tissue. One of such processes could be the substitution of ions from the crystal grid of the apatite by an $\mathrm{N}-\mathrm{O}$ ion from the marker molecule.

The available reference data on the properties of diffusion in the enamel (Borggreven, 1980; Dibdin,1972; Chick, 1963; Kambera,1977 and Funduk,1975) can only be roughly compared. Analyses of diffusion process of water, sodium and manganese in the enamel tissue represent unilateral diffusion processes, whereas diffusion of the organic spin market 4-Amino-Tempo is the result of a bilateral diffusion process (Tihaček-Šojić, 2002; 2004).

\section{CONCLUSIONS}

From the results the following may be concluded:

I. organic molecules of the 4-Amino-Tempo spin marker diffused through enamel tissue

II. diffusion of the organic molecules is a bilateral process which is characterized by the concentration of diffused molecules and the diffusion coefficient.

III. In the intact and fresh non-intact enamel tissue during diffusion a maximum quantity of diffused organic molecules is observed after several weeks. Their diffusion coefficients have almost the same values

IV. With the old non-intact enamel tissues, harmful consequences of leaving the reduced enamel tissue without any protection ara observed

Address for correspondence:

Ljiljana Tihaček-Šojić

Gundulićev venac 55, 11000 Belgrade

Serbia \& Montenegro

E-mail: sojic@net.yu 


\section{REFERENCES}

1. Arwill T, Myrberg N, Soremark R, 1965, Penetration of radioactive isotopes through enamel and dentine, I. Diffusion of $22 \mathrm{Na}$ in fresh and coagulated dental tissues, J Dent Res, 44, 6, 1299303.

2. Beloica D, Stošić P, Pavićević M, 1980, Investigation of fluoride distribution in hard teeth tissue by MP and Sem methods, Electron Microscopy, 3, 108-10.

3. Borggreven JMPM, van Dijk JWE, Driessens FCM, 1977, A quantitative radiochemical study of ionic and molecular transport in bovine dental enamel, Arch Oral Biol, 22, 467-72.

4. Borggreven JMPM, Driessens FCM, van Dijk JWE, 1980, Diffusion through bovine tooth enamel as related to the water structure in its pores, Arch Oral Biol, 25, 345-8.

5. Borowsky EV, Sazanov NI, 1978, Changes of permeability of dental enamel following distant gamma irradiation of the mandible, Stomatologia (Moskva), 57, 1-5.

6. Burke EJ, Moreno EC, 1975, Diffusion fluxes of tritiated water across human enamel membranes, Arch Oral Biol, 20, 327-32.

7. Cevs P, Schara M, Ravnik L, Skaleri U, 1976, Study of the arrangement of crystallites in irradiated human enamel by electron paramagnetic resonance, J Dent Res, 55, 691-5.

8. Cevs P, Schara M, Skaleri U, Terelvi D, 1976, Crystallite arrangement of hydroxyapatite microcrystals in tooth cementum, Zobozdrav Vestn, 41, suppl 1, 117-26.

9. Chick AO, Waters NE, 1963, Membrane patentials in teeth: Application of some common anions to enamel, J Dent Res, 42, 4, 934-42.

10. Dibdin GH, 1972, The stability of water in human dental enamel studied by proton nuclear magnetic resonance, Arch Oral Biol, 17, 433-7.

11. Doi Y, Aoba T, Okazaki M, Takahashi J, Moriwaki Y, 1979, Analysis of paramagnetic centers in X-ray irradiated enamel, bone and carbonate-containing hydroxyapatite by electron spin resonance spectroscopy, Cals Tissue Int , 28, 107-12.

12. Doi $Y, 1986$, Esr studies of tooth enamel, Zobozdrav Vestn, 41, Suppl. 1, 43-58.

13. Funduk N, Ravnik L, Cevs P, Schara M, 1975, Diffusion and distribution of manganese ions in tooth enamel, Period Biol, 77, 140.

14. Funduk N, Schara M, Cevs P, 1986, Polimerization of cold cured acrylic resin studied by EPR, Zobozdrav Vestn, 41, suppl. 1, 187-95.

15. Funduk N, Lahajnar G, Miljković L, Skočajić S, Kydon DW, Schrener LJ, Pintar MM, 1986, A comparative NMR study of proton groups in dentin of 20 and 50 years old donors, Zobozdrav Vestn, 41, suppl. 1: 139-60.

16. Gwinett AJ, 1966, The ultrastructure of the "prismless" enamel of deciduous teeth, Archs Oral Biol, 11, 1109-15.

17. Gwinett AJ, 1967: The ultrastructure of the "prismless" enamel of permanent human teeth, Archs Oral Biol, 12, 381-7.

18. Johnson NW, Poole DFG, Tyler JE, 1971, Factors affecting the differential dissolution of human enamel in acid and EDTA. A scaning electron microscope study, Archs Oral Biol, 16, 385-96.

19. Kambara M, Konshi K, 1977, Study on the ion permeability of human dental enamel with special reference to an electrochemical approach, J Osaka Dental Univ, 11, 48-57.

20. Little MS, Cascani FS, 1966, The nature of water in sound human enamel, Arch Oral Biol, 11, 56571.

21. Ripa LW, Gwinett AJ, Buonocore MG, 1966, The "prismless" outer layer of deciduous and permanent enemel, Arch Oral Biol, 11, 41-8.

22. Silverstone LM, Poole DFG, 1986, The effect of saliva and calcifying solutions upon the histological appearance of enamel caries, Caries Res, 2, 87-96.

23. Skalerič U, Funduk N, Ravnik Č, Cevs $P$, Schara M, 1981, Elektronska paramagnetna resonanaca in njena uporaba v stomatoloških raziskavah, Zobozdravstveni vestnik, 5-6, 113-6.

24. Skalerič U, Ravnik Č, Cevs $P$, Schara M, 1982, The microcrystal arrangement in human deciduous teeth enamel studied by electron paramagnetic resonance. Caries Res., 16, 47-50. 
25. Skalerič U, Cevs P, Ravnik Č, Schara M, 1986, Transport and binding of spin probes in human tooth cementum, Zobozdravstveni Vestnik, 41, Suppl. 1, 161-75.

26. Skalerič U, Dolinšek J, 1986, Proton spin lattice relaxation time $T_{1}$ in gingival fluid, Zobozdravstveni Vestnik, 41, S-1, 179-87.

27. Spektrova Al, Borisova MN, 1967, The permeability of the dental enamel in experiments on animals, Stomatologia (Moskva), 46, 14-7.

28. Stern MA, Brudvić JS, Frank RP, 1985, Clinical evaluation of removable partial denure rest seat adaptation, J Prosth Dent, 53, 5, 658-62.

29. Schwancar JR, Scott DB, Njemirovskij Z, 1970, Studies of the structure of human enamel by the replica method, J Dent Res, 49, 1025-33.

30. Tihaček Šojić, Đurić M, 1997, Analyses of the optical properties of mediaval enamel, Dental Antrophology, 13, 1, 14-20.

31. Tihaček Šojić, Milićević V, Đurić M, 1997, Crystalographic and colorimetric analyses of dental enamel, Dental Antrophology, 11, 2, 5-11.

32. Toth R, Fiebiger G, Mackert R, Goldman B, 1986, Assesment of microleakege of restorative materials by a diffusion model, $J$ Oral Rehabil, 13, 355-63.

33. Vrbošek V, Ravnik Č, Škrk J, 1973, Penetration bakterieller Antigene markiert mit J-131 durch intakten Schmelz und durch das Dentin in vivo, Deutch Zahnarztl Z, 28, 307-11.

34. Waters NE, 1971, The selectivity of human dental enamel to ionic transport, Arch Oral Biol, 16, 30522.

35. Weatherell JA, Weidmann SM, Hamm SM, 1967, Density patterns in enamel, Caries Res, 1, 42-51.

36. Weidmann SM, Weatherell JA, Hamm SM, 1967, Variations of enamel density in sections of human teeth, Arch Oral Biol, 12, 85-97.

37. Young RA, 1974, Implications of atomic supstitutions and other structural details in apatites, J Dent Res, 53, 193-203.

\title{
DUBINA DIFUZIJE ORGANSKIH MOLEKULA U GLEĐNOM TKIVU KOD PASA
}

\author{
LJILJANA TIHAČEK - ŠOJIĆ
}

\section{SADRŽAJ}

$\mathrm{U}$ ovom radu prikazani su rezultati dubine difuzije organskih molekula u gleđnom tkivu stalnih zuba. Eksperimentalna istraživanja in vivo vršena su na psima. Na molarima desne strane donje vilice , kod svih životinja eksperimentalno je izvršena redukcija gleđnog tkiva, bez postavljanja zaštite, dok su zubi leve strane mandibule ostali intaktni i predstavljali su kontrolnu grupu.Period in vivo je trajao 12 meseci, posle čega su životinje žrtvovane, eksperimentalni I kontrolni zubi izolovani I nastavljeno ispitivanje procesa difuzije in vitro. $U$ te svrhe izabran je organski spinski marker 4-amino-2,2,6,6-teramentil-piperidinil-1-oksi (4-Amino Tempo). Osobina ovog markera je da ima u svom sastavu nitroksidni radikal koji je stabilan u neutralnoj i baznoj sredini, a zbog nesparenog spina slobodnog radikala veoma je pogodan za istraživanja metodom elektronske paramagnetne resonance. 
Ispitivanja difuzije organskog spinskog markera u gleđnom i dentinskom tkivu su izvršena potapanjem zubnih preparata u vodeni rastvor markera. Iz inteziteta EPR spektara, snimljenih na preparatima posle njihovih vađenja iz vodenog rastvora, ustanovljena je raspodela broja difundovanih molekula markera u preparatima u zavisnosti od vremena difuzije i dubine prodiranja. Određeni su koeficijenti difuzije organskog spinskog markera za gleđ i dentin i saturaciona koncentracija molekula markera u gleđnim preparatima. Uočene varijacije u prostornoj i vremenskoj raspodeli roja difundovanih molekula objašnjene su sa mogućnošću vezivanja $\mathrm{N}-\mathrm{O}$ - radikala iz molekula markera za gleđno tkivo.

Rezultati eksperimentalnih istraživanja sadržani u ovom radu doprinose boljem razumevanju procesa kretanja molekula organskog spinskog markera kroz gleđno tkivo koji je kontrolisan mehanizmom difuzije i hemijskim vezivanjem molekula markera za strukturu gleđi. Rezultati eksperimentalnih istraživanja takođe ukazuju na moguće štetne posledice ostavljanja redukovanog gleđnog tkiva bez zaštite. 